\title{
Entrepreneurial Strategy Orientation
}

\author{
Henri Hakala
}

\begin{abstract}
The paper explores the concept of strategic entrepreneurship through strategic orientation literature. The paper proposes that the orientation supporting entrepreneurial strategy making, consist of complementary dimensions of entrepreneurial exploration, strategic learning, resource management and market positioning. The proposed multidimensional dynamic capability, entrepreneurial strategy orientation, provides the principles that direct and influence the activities associated with strategic entrepreneurship. The paper contributes by providing a framework for the transfer of knowledge from the established literature on strategic orientations to strategic entrepreneurship research. Fundamentally, the framework proposes that directing a company based on a single philosophy, be it resources, market positions, learning or entrepreneurial actions, is simply not going to be adequate in multi-polar world and in competition against firms that have mastered multiple approaches.
\end{abstract}

Index Terms-Strategic entrepreneurship, dynamic capability, strategic orientations.

\section{INTRODUCTION}

The dynamics between exploiting the current market opportunities and exploring new possibilities plays ever greater role in the globalizing world. While the competition grows ever more sophisticated in the developed markets, the search of new opportunities elsewhere becomes more attractive. Strategic entrepreneurship research combines the viewpoints of entrepreneurship and strategy literature and deals with the actions firms take to simultaneously combine the opportunity and advantage seeking behaviors [1], [2]. The prior research has modeled strategic entrepreneurship through dimensions of entrepreneurial mindset, -culture and -leadership in combination with strategic management of resources and creativity in developing innovations [1]. Resources, capabilities, strategy, the entrepreneur, organizational structure and the environment are all relevant domains for strategic entrepreneurship [3]. To propose further insight into the conceptual nature of strategic entrepreneurship, this paper approaches it through the strategic orientations perspective. Strategic orientations may be described as guiding templates for the ways organizations conduct their business activity [4], or principles that direct and influence the activities of a firm and generate the behaviors intended to ensure the viability and performance of the firm [5]. The definition suggests that strategic orientation captures some of the underlying principles that may, or may not, generate the simultaneous opportunity and advantage seeking behaviors commonly described as

Manuscript received September 1, 2013; revised November 8, 2013.

Henri Hakala is with the University of Vaasa, Department of Management, Vaasa, Finland (e-mail: firstname.lastname@uwasa.fi). strategic entrepreneurship. Therefore, the paper sets out to investigate what kind of strategic orientation might support the ascendance of strategic entrepreneurship within firms.

Over the years, scholars have developed a number of different constructs that attempt to explain, the adaptation of firms, and for this purpose, the various orientation constructs have been hugely popular among scholars in different disciplines. However, only more recently, scholars have begun to investigate the links between these orientation constructs developed within strategic management, entrepreneurship and marketing literatures, resulting in an emerging stream of literature considering different orientations as complementary constructs that exist simultaneously within the companies and jointly support the performance of firms (for review of this literature see: Hakala 2011 [6], for statistical meta-analysis see: Grinstein 2008 [7]. The multi-orientation studies suggest that balancing several orientations tends to result in better performance [7]-[9], and suggest that research should focus on the combinations of strategic orientations that firms can pursue in different situations [7], [10], [11].

The idea of multiple simultaneous orientations is clearly parallel to that of strategic entrepreneurship, in its attempt to combine the views of strategic management with entrepreneurship research. Accordingly, this paper follows on from the more general developments in management theory that suggest dichotomous models (such as market vs. product) towards simultaneous application of, apparently contradictory, orientations. This is converted to a view in which strategic orientation is seen as a combination of the value position of a firm in the markets, its resources and behavioral patterns relating to how the organization transforms its resources into products and services to suit the marketplace.

The main objective of this paper is to configure the concept of entrepreneurial strategic orientation, the principles governing the activities constituting strategic entrepreneurship. This is achieved by integrating four different views on strategic orientation, and results in conceptual idea of the principles that are required for simultaneous opportunity and advantage seeking behaviors. The framework perceives the concept of strategic entrepreneurship through a combination of resource-, entrepreneurial- market- and learning orientation viewpoints. The framework is also illustrated through empirical examples based on a test data (n164) collected from the software sector.

\section{StRategic ORIENTATIONS}

Porter's (1980) famous classification of generic strategies [12], as well as Miles and Snow (1978) strategy types [13] have sometimes been referred as strategic orientations, yet it 
appears that Venkatraman (1989) [14] first used the term strategic orientation. He defined strategic orientation through the dimensions of strategic aggressiveness, analysis, defensiveness, futurity, proactiveness and riskiness and suggests that the strategic orientation of an organization may be measured through managerial perceptions and beliefs on the organizational processes on these six dimensions. For Venkatraman strategic orientation was a device to assess and measure the key dimensions of business level strategy [14] and many of these dimensions relate to the concept of entrepreneurial orientation (entrepreneurial vs. conservative strategic posture) as introduced by Miller (1983) [15]. However, since these early contributions strategic orientation has acquired a meaning extending beyond the initial construct. Strategic orientation is commonly used as generic, umbrella term to describe a number of different constructs such as market orientation, entrepreneurial orientation, learning orientation or technology orientation. Many writers also consider the orientations as a type of dynamic capability that may be measured across organizations [16], [17]. Each of these orientations suggests a different mechanism for adaptation and thus, responds differently to the question of how firms should compete within their chosen product-market segments.

Strategic management literature often argues that the possession of valuable, rare, difficult to imitate and imperfectly substitutable resources [18]-[20], as well as favorable market position [21] are both sources of competitive advantage. Resource, technology, or product orientations essentially approach the dilemma of adaptation from the internal angle and link closely with the resource-based view of the firm by suggesting that the performance is a result of the development of unique resource combinations that result in new technologies, products or processes that enable firms to gain a competitive edge over the competition [5], [7], [22]. The market positioning view of strategic management links with the concepts of market; customer and competitor orientations developed by marketing scholars. Generally, the market orientation viewpoint argues that organizations should adapt to the environment by value positioning themselves correctly in the markets through superior understanding of their customers and competitors [23], [24]. More recently, studies have also suggested that this is further enhanced by combining market orientation with entrepreneurial behaviors [25], [26].

Entrepreneurship literature puts an emphasis on the new creating, opportunity seeking, and explorative behaviors. The entrepreneurial orientation proposes that innovativeness and proactivity along with risk-taking characterize organizations that perform well by constantly changing the dynamics of the marketplace [15], [27]-[29]. Entrepreneurially-oriented organizations change and shape the environment and are willing to commit resources to exploit uncertain opportunities. They explore new and creative ideas that may lead to changes in the marketplace and do so proactively ahead of the competition in anticipation of future demand. This kind of better adjustment and shaping of the environment should have positive effects on firm performance [22], [29], [30], [31]. Entrepreneurial orientation is essentially a growth orientation [32], referring to processes and practices that lead to 'new entry'- that is start of new business, entering new markets or introducing new products into existing markets [28]. However, recent studies have proposed that entrepreneurial firms may be balancing their entrepreneurial orientation with learning oriented behaviors in synergetic relationship [33]. Learning orientation suggests that organizations with an open mind and commitment to continuously learn at an organizational level generate a shared vision of the future that enables them to adapt to changes in their environment and therefore also exploit the current opportunities better [34]-[36]. Many scholars distinguish between strategy content and strategy process perspectives. The content perspective argues that competitive advantage results from the content of strategies that relate to competitors such as uniquely valuable resource combinations (Resource-Based View) or positions in the markets [12]. In turn, the process perspective argues that competitive advantage results from processes such as analysis and planning, learning and development, or entrepreneurial behaviours. However, some others may not make such distinctions [37], and findings [38] suggest that managers in practice also integrate these views and perceive strategy as a combination of processes and content. The existing orientation constructs have often multiple dimensions, some of which relate to content, other to processes. Thus, suggesting that effective strategic orientation supporting strategic entrepreneurship contains elements of both process and content of strategy. Consequently, this paper conceptualizes the strategic entrepreneurship orientation of the firm through the idea that strategic entrepreneurship consists of activities that focus on 1) developing technological and other resources, 2) serve and satisfy their customers 3) seek new opportunities to deploy resources and satisfy more customers and 4) continuously learn to become more efficient and effective in all these aspects.

\section{STRATEGIC ENTREPRENEURSHIP AS CONFIGURATION OF ORIENTATIONS}

The idea is to put forward a concept of strategic orientation as a combination of the positions and resources of a firm, exemplified through the concepts of market- and resource orientation. On the other hand, the more process related discussion on the exploration - exploitation axis is conducted through the concepts of entrepreneurial and learning orientation. These are not considered opposites, but complementary processes enabling firms to find competitive advantages, through simultaneous exploitation and exploration of both resources and market positions. In essence, this conception of strategic orientation combines the four different viewpoints within the idea of strategic entrepreneurship orientation. This aligns with the basic idea of strategic entrepreneurship in which resources are managed strategically but entrepreneurially, in order to both maintain competitive advantage as well as explore new market positions. The synergetic relationships between the dimensions appear reasonable to expect. The discovery of opportunity is necessary before it can be acted upon and 
made profitable. Yet, the possession of prior knowledge, is a necessary precondition for recognizing new the opportunity recognition opportunities [39]. While entrepreneurial organizations may take decisions on a purely intuitive basis, it could be suggested that strategic learning and management extends the stock of information from which opportunities may be recognized. Similarly, studies have found complementarity between entrepreneurial behaviors and utilization of market knowledge both in positioning the company as well as utilizing resources innovatively towards new customer groups [26].

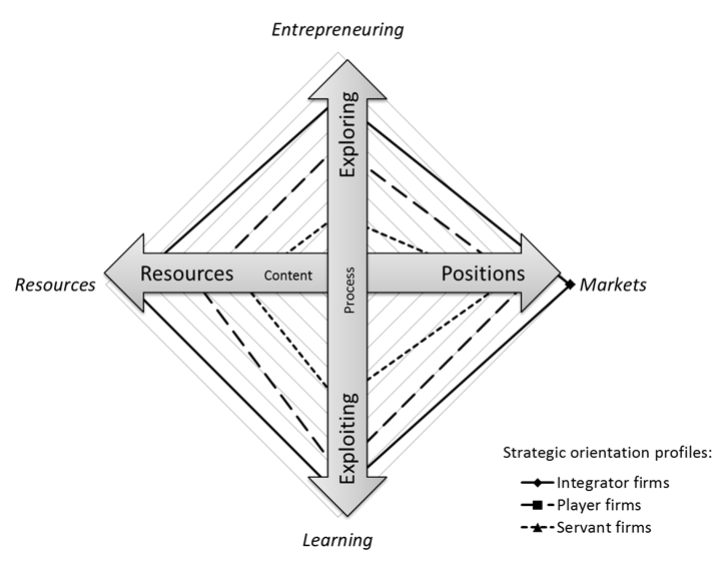

Fig. 1. Strategic entrepreneurship orientation as configuration. The integrator firms appear to align most closely with the ideas of strategic entrepreneurship and appear to also perform significantly better than the servant firms. The 'Integrator', 'Player' and 'Servant' are examples of potential configuration profiles that were found using cluster analysis on a test data (n164) collected from software companies. All the usual tests for reliability and validity of the data were performed and results were satisfactory, however the underlying measures need some development and the profiles are presented here only as illustration of the use for the theoretical framework.

\section{CONCLUSIONS}

The presented form of strategic entrepreneurship orientation is very malleable in terms of the underlying measures on each dimension. However, that is not to suggest that any old orientation measures could just be bundled together. It is extremely important that different dimensions are indeed different, and yet, compatible views, and do not have significant overlaps. This requires careful and accurate assessment of the relationship and discriminant validity between the measures. However, the concept may be adjusted to assess those dimensions found to be important for the research context. For example, technology orientation as in illustration, may be chosen to represent 'resources' in industries where the ability to utilize high technology is perceived particularly important, while investigations into pure service firms might adapt different kind of measure for the resource-based dimension of the model.

Overall, this paper contributes by presenting a framework for understanding strategic entrepreneurship through the lens of orientations literature. Large number of studies has been conducted and lot of knowledge has been accumulated using the orientation constructs. Therefore, an important contribution of this lens is that allows the transfer of some of that knowledge into the strategic entrepreneurship literature. Furthermore, while one has to be very careful in doing this, the orientation literature may provide useful reference point in developing measures for strategic entrepreneurship and its dimensions.

For managers, this kind of idea of strategic orientation encourages a development of a more holistic view and awareness on the strategic directions of the firm. Directing the company based on a single philosophy, be it resources, market positions, learning or entrepreneurial actions, is simply not going to be adequate in multi-polar world and in competition against firms that have mastered multiple approaches.

While the framework presented lacks major empirical tests, already the multidimensional strategic orientation construct could be put into practice to facilitate strategy discussions, and would prompt the management team to approach situations from different viewpoints. Thus, this kind of malleable, but abstract theoretical concept could facilitate the ascendance of a more holistic, shared view within top management teams, and further on, provide a richer, but consistent framework, within which the organization may take the more operational decisions secure in the knowledge that they are aligned with the overall strategy.

\section{REFERENCES}

[1] R. D. Ireland, M. A. Hitt, and D. G. Sirmon, "A model of strategic entrepreneurship: The construct and its dimensions," Journal of Management, vol. 29, no. 6, pp. 963-989, 2003.

[2] R. D. Ireland and J. W. Webb, "Strategic entrepreneurship: Creating competitive advantage through streams of innovation," Business Horizons, vol. 50, pp. 49-59, 2007.

[3] S. Kraus, I. Kauranen, and C. H. Reschke, "Identification of domains for a new conceptual model of strategic entrepreneurship using the configuration approach," Management Research Review, vol. 34, no. 1, pp. 58-74, 2011.

[4] P. Berthon, J. Hulbert, and L. F. Pitt, "To serve or create? Strategic orientations towards customers and innovation," California Management Review, vol. 42, no. 1, pp. 37-58, 1999.

[5] H. Gatignon and J. M. Xuereb, "Strategic orientation of the firm and new product performance," Joumal of Marketing Research, vol. 34, no. 1, pp. 77-90, 1997.

[6] H. Hakala, "Strategic orientations in management literature: three approaches to understanding the interaction between market, technology, entrepreneurial, and learning orientations," International Journal of Management Reviews, vol. 13, no. 2, pp. 199-217, 2011.

[7] A. Grinstein, "The relationships between market orientation and alternative strategic orientations a meta-analysis," European Journal of Marketing, vol. 42, no. 1/2, pp. 115-134, 2008.

[8] K. A. Gima and A. Ko, "An empirical investigation of the effect of market orientation and entrepreneurship orientation alignment on product innovation," Organization Science, vol. 12, no. 1, pp. 54-74, 2001.

[9] S. N. Bhuian, B. Menguc, and S. J. Bell, "Just entrepreneurial enough: the moderating effect of entrepreneurship on the relationship between market orientation and performance," Journal of Business Research, vol. 58, no. 1, pp. 9-17, 2005.

[10] W. S. Aloulou and A. Fayolle, "A conceptual approach of entrepreneurial orientation within small business context," Journal of Enterprising Culture, vol. 13, no. 1, pp. 24-45, 2005.

[11] Y. Li, Y. Zhao, J. Tan, and Y. Liu, "Moderating effects of entrepreneurial orientation on market orientation-performance linkage: Evidence from chinese small firms," Journal of Small Business Management, vol. 46, no. 1, pp. 113-133, 2008.

[12] M. E. Porter, Competitive Strategy. Techniques for Analyzing Industries and Competitors, Free Press, New York, NY, 1980.

[13] R.E. Miles and C. C. Snow, Organizational strategy, structure and process. New York: McGraw-Hill, 1978.

[14] N. Venkatraman, "Strategic orientation of business enterprises: The construct, dimensionality, and measurement," Management Science, vol. 35, no. 8, pp. 942-962, 1989.

[15] D. Miller, "The correlates of entrepreneurship in three types of firms," Management Science, vol. 29, no. 7, pp. 770-790, 1983. 
[16] M. L. S. Vijande, M. J. S. Pérez, L. I. Á. González, and R. V. Casielles, "Organizational learning and market orientation: interface and effects on performance," Industrial Marketing Management, vol. 34, no. 3, pp. $187-202,2005$

[17] K. Z. Zhou, C. K. B. Yim, and D. K. Tse, "The effects of strategic orientations on technology- and market-based breakthrough innovations," Journal of Marketing, vol. 69, no. 2, pp. 42-60, 2005.

[18] J. B. Barney, "Firm resources and sustained competitive advantage," Journal of Management, vol. 17, pp. 99-120, 1991.

[19] J. B. Barney, "Looking inside for competitive advantage," Academy of Management Executive, vol. 9, no. 4, pp. 49-61, 1995

[20] C. K. Prahalad and G. Hamel, "The core competence of the corporation," Harvard Business Review, vol. 68, no. 3, pp. 79-91, 1990.

[21] M. E. Porter, Competitive Advantage: Creating and Sustaining Superior Performance, Free Press, New York, NY, 1985.

[22] G. T. M. Hult, R. F. Hurley, and G. A. Knight, "Innovativeness: Its antecedents and impact on business performance," Industrial Marketing Management, vol. 33, no. 5, pp. 429-438, 2004.

[23] G. S. Day, "The capabilities of market-driven organizations," Journal of Marketing, vol. 58, no. 4, pp. 37-52, 1994.

[24] J. Narver and S. Slater, "The effect of a market orientation on business profitability," Journal of Marketing, vol. 54, no. 4, pp. 20-35, 1990.

[25] J. C. Narver, S. F. Slater, and D. L. M. Lachlan, "Responsive and proactive market orientation and new-product success," Journal of Product Innovation Management, vol. 21, pp. 334-347, 2004.

[26] W. E. Baker and J. M. Sinkula, "The complementary Effects of Market Orientation and Entrepreneurial Orientation on Profitability in Small Businesses," Journal of Small Business Management, vol. 47, no. 4, pp. 443-464, 2009.

[27] J. G. Covin and D. P. Slevin, "Strategic management of small firms in hostile and benign environments," Strategic Management Journal, vol. 10 , no. 1, pp. $75-87,1989$.

[28] G. T. Lumpkin and G. G. Dess, "Clarifying the entrepreneurial orientation construct and linking it to performance," Academy of Management Review, vol. 21, no. 1, pp. 135-172, 1996.

[29] J. Wiklund and D. Shepherd, "Entrepreneurial orientation and small business performance: a configurational approach," Journal of Business Venturing, vol. 20, no. 1, pp. 71-91, 2005.

[30] H. K. Keh, T. T. M. Nguyen, and H. P. Ng, "The effects of entrepreneurial orientation and marketing information on the performance of SMEs," Journal of Business Venturing, vol. 22, no. 4, pp. 592-611, 2007.
[31] J. Wiklund, "The sustainability of the Entrepreneurial Orientation Performance relationship," Entrepreneurship Theory and Practice, vol. 24, no. 1, pp. 37-48, 1999.

[32] J. G. Covin, K. M. Green, and D. P. Slevin, "Strategic process effects on the entrepreneurial orientation-sales growth rate relationship," Entrepreneurship Theory and Practice, vol. 30, no. 1, pp. 57-81, 2006.

[33] B. S. Anderson, J. G. Covin, and D. P. Slevin, "Understanding the relationship between entrepreneurial orientation and strategic learning capability: An empirical investigation," Strategic Entrepreneurship Journal, vol. 3, pp. 218-240, 2009.

[34] W. E. Baker and J. M. Sinkula, "The synergistic effect of market orientation and learning orientation on organizational performance," Academy of Marketing Science Journal, vol. 27, no. 4, pp. 411-427, 1999.

[35] W. E. Baker and J. M. Sinkula, "Learning Orientation, Market Orientation, and Innovation: Integrating and Extending Models of Organizational Performance," Journal of Market Focused Management, vol. 4, no. 4, pp. 295-308, 1999.

[36] R. J. Calantone, S. T. Cavusgil, and Y. Zhao, "Learning orientation, firm innovation capability, and firm performance," Industrial Marketing Management, vol. 31, no. 6, pp. 515- 524, 2002.

[37] H. Minzberg and J. Lampel, "Reflecting on the strategy process," Sloan Management Review, vol. 40, no. 3, pp. 21-30, 1999.

[38] I. A. Combe, "Strategic orientations in practice. Exploring the strategy belief stuctures of line-managers embedded in practice," Aston University, 2006.

[39] S. Shane and S. Venkataraman, "The promise of entrepreneurship as a field of research," The Academy of Management Review, vol. 25, no. 1, pp. 217-226, 2000.

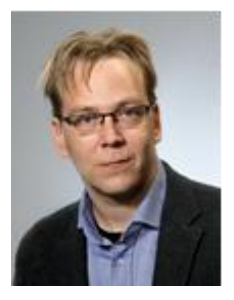

Henri Hakala was born in Finland in 1975. He has received his Ph.D. in management and organization from the University of Vaasa, Department of Management. He has several years of managerial experience from the automotive industry in different countries and currently works as a post-doctoral research fellow in the University of Vaasa. Dr. Hakala's research interests include business strategy, value creation and entrepreneurship. 